\title{
The seroprevalence of hepatitis A in Istanbul, Turkey
}

\author{
İstanbul'da hepatit A seroprevalans1
}

Aslı KARADENİ, Elçin AKDUMAN ALAŞEHİR, Zuhal YEŞİLBAĞ, Ahmet BALIKÇI, Görkem YAMAN

\begin{abstract}
Objective: Hepatitis A, a leading cause of enterically transmitted acute viral hepatitis throughout the world, has changed its pattern in developing countries. The objective of this study is to determine the current seroprevalence of hepatitis A virus (HAV) for different age groups in Istanbul, Turkey.

Materials and Methods: Serum samples of 3,868 patients, which had been previously taken, were used to determine anti-HAV IgG levels by the microparticle enzyme immunoassay (MPEIA) method (Architect SR 11000 and i2000, Abbott Diagnostics, Germany) between January 2011 and December 2013.

Results: The prevalence of total anti-HAV antibodies was $64.8 \%$ for all patients. Among the 3,868 serum samples tested, $54 \%$ were from male patients and $46 \%$ were from female patients. Seropositivity rates among the age groups were determined and antiHAV antibody positivity rates were $55 \%$ for the $0-16$ age group; $47 \%$ for the $17-30$ age group; $73.5 \%$ for the $31-45$ age group and the seroprevalence increased significantly from $50 \%(972 / 1944)$ in 0 to 30 years old to $89 \%$ in patients older than 46 years.

Conclusion: The low seronegativity rates in young adults, show this group to be at high risk of acquiring an HAV infection. The results support the routine vaccination of children and the seronegative young adults against HAV.
\end{abstract}

Keywords: Hepatitis A virus, Seroprevalence, Hepatitis A vaccine

Aslı Karadeniz ( $\square)$

Department of Infectious Diseases and Clinical Microbiology, School of Medicine, Maltepe University, Istanbul, Turkey

e-mail: larin_88@yahoo.com

Elçin Akduman Alaşehir

Department of Clinical Microbiology, School of Medicine, Maltepe University, Istanbul, Turkey

Zuhal Yeşilbağ

Infectious Diseases and Clinical Microbiology Clinic, Bakirkoy Dr. Sadi Konuk Education and Research Hospital, Istanbul, Turkey

Ahmet Balıkçı

Clinical Microbiology, Sureyyapasa Chest Diseases and Surgery Training and Research Hospital, Istanbul, Turkey

Görkem Yaman

Clinical Microbiology, Düzen Laboratory, Istanbul, Turkey

Submitted / Gönderilme: 21.10.2016

Accepted/Kabul: 11.12 .2016 öz

Amaç: Dünya genelinde akut viral hepatitin önde gelen nedenlerinden olan ve enterik yolla bulaşan hepatit A infeksiyonu, gelişmekte olan ülkelerde değişim göstermiştir. $\mathrm{Bu}$ çalışmanın amacı İstanbul, Türkiye'de farklı yaş gruplarında hepatit A virusu (HAV) seroprevalansının güncel durumunu belirlemektir.

Gereçler ve Yöntemler: Ocak 2011 ve Aralık 2013 yılları arasında 3,868 hastaya ait serum örneklerinde anti-HAV IgG değerleri mikropartikül enzim immunoassey (MPEIA) yöntemi (Architect SR i1000 and i2000, Abbott Diagnostics, Germany) ile retrospektif olarak değerlendirilmiştir.

Bulgular: Çalışmada, tüm hastalarda total anti-HAV antikor prevalans1 \%64,8 olarak saptanmıştır. Değerlendirilen 3,868 serumun \%54'ü erkek ve \%46'sı kadın hastalardan elde edilmiştir. Yaşlara göre seropozitiflik oranları; 0-16 yaş arasında \%55, 17-30 yaş arasında \%47, 31-45 yaş arasında \%73,5 olarak belirlenmiştir. 0-30 yaş arasında \%50 (972/1944) olan seroprevalans oranı; 46 yaş üzerindeki grupta $\% 89$ oranı ile anlamlı artış ortaya koymaktadır.

Sonuç: Genç yaş grubundaki seropozitiflik oranlarının düşük olması, bu grubu HAV infeksiyonu açısından daha riskli kılmaktadır. Sonuçlar, çocukların ve seronegatif genç yetişkinlerin HAV'e karşı rutin olarak aşılanmasını desteklemektedir.

Anahtar kelimeler: Hepatit A virüs, Seroprevalans, Hepatit A aş1s1

\section{Introduction}

Hepatitis A virus (HAV) is an important and common cause of viral hepatitis worldwide with major differences in geographical endemicity and clinical characteristics [1-3]. It is usually a self-limited disease but can result in fulminant hepatitis and death and it is a significant cause of morbidity and socioeconomic losses in many parts of the world [2]. Transmission of HAV is predominantly by direct person-toperson contact through the orofecal route where sanitation is poor and living conditions are crowded [1,2]. Infections occur early in life. Improvements in sanitation and hygiene 
have resulted in reduction in the rate of childhood exposure in some countries [2]. Since, most infections, especially in children, are subclinical, we can estimate HAV infection prevalence in a population by determination of the antiHAV antibodies [4]. The distribution of anti-HAV antibody seroprevalence over several age groups can be used as a marker of a useful HAV epidemiologic pattern relating to viral transmission through a community [5]. Serologic studies help to determine the patterns of endemicity which have been identified as low, medium and high. HAV is a worldwide virus but highly endemic in developing countries $[1,4]$. The seroprevalence of HAV in Turkey varies among geographical regions, but most regions have an intermediate endemicity [6,7]. HAV infections can be prevented by immunization and HAV vaccine may be used for prophylaxis [5].

This study determined the age specific seroprevalence of HAV in Istanbul,Turkey.

\section{Materials and Methods}

Serum samples were collected from patients of a university hospital laboratory and 2 diagnostic laboratories located in different regions of Istanbul, which is the most crowded city of Turkey. Istanbul is a province which is located in NorthWest Turkey with 14 million inhabitants most of whom are immigrants from all regions of the country with variable socioeconomic levels. A total of 3,868 serum samples were analysed from, Istanbul, Turkey between January 2011 and December 2013. Serum samples were tested to detect anti-HAV $\mathrm{IgG}$ by microparticle enzyme immunoassay (MPEIA) method (Architect SR i1000 and i2000, Abbott Diagnostics, Germany). Serums were assigned with codes, and demographic characteristics available were age, gender, district of laboratory and date of sampling. Serum samples were collected from subjects aged 1-79 years and were stratified into the following age groups; 0-16, 17-30, 31-45 years and above 46 years of age. In this study patients' data were analyzed anonymously. This study was approved by the Institutional Ethics Committee.

\section{Statistical Analyses}

Statistical analyses were performed using SPSS for Windows version 16. Chi-squared test and Fisher's exact test were used, considering a value of $\mathrm{P}<0.05$ as statistically significant.

\section{Results}

Among the serum samples tested, $54 \%(2,092 / 3,868)$ were from male patients and $46 \%(1,776 / 3,868)$ were from female patients. There was no difference in seroprevalence between gender groups (male 66\% and female 63\%) $(\mathrm{P}>0.05)$. The overall seroprevalence rate of anti-HAV among the study population was $64.8 \%$ (Table I). Anti-HAV seroprevalence according to the age groups $0-16,17-30,31$ 45 years and over 46 years old were $55 \%, 47 \%, 73.6 \%$ and $89 \%$, respectively. The seroprevalence was relatively low in people under 30 years of age, ranging from $47 \%$ to $55 \%$. An increase in seropositivity with age was observed in the older age groups; the seroprevalence increased from $50 \%$ $(972 / 1,944)$ in 0 to 30 years old to $89 \%$ in patients older than 46 years $(\mathrm{P}<0.05)$ (Table II).

Table I. HAV seropositivity and gender difference

\begin{tabular}{cccc}
\hline Gender & Positivite (\%) & Negative (\%) & Total \\
\hline Male & $1,384(66.2)$ & $708(33.8)$ & $2,092(100)$ \\
Female & $1,124(63.3)$ & $652(36.7)$ & $1,776(100)$ \\
Total & $2,508(64.8)$ & $1,360(35.2)$ & $3,868(100)$ \\
\hline
\end{tabular}

Table II. Anti-HAV IgG results according to age groups

\begin{tabular}{cccc}
\hline Age & Positivite (\%) & Negative (\%) & Total \\
\hline $0-16$ & $392(55)$ & $317(45)$ & 709 \\
$17-30$ & $580(47)$ & $655(53)$ & 1235 \\
$31-45$ & $853(73.6)$ & $305(26.4)$ & 1158 \\
$>46$ & $683(89)$ & $83(11)$ & 766 \\
\hline
\end{tabular}

\section{Discussion}

The HAV seroprevalence in a total of 3,868 patients aged between 1-79 in Istanbul was detected to be $64.8 \%$. Turkey has an intermediate level of anti-HAV seroprevalence with differences among various geographical regions [7,8]. A recent study which was conducted with 1,173 individuals (0-91 years old) in five different geographical regions of Turkey found the overall prevalence of anti-HAV antibodies to be $64.4 \%$ [9]. Although, the authors found differences among geographical regions in Turkey (high in SouthEastern and Eastern regions and low in central and Western regions), the overall seropositivity is similar to our results 
in Istanbul, which is located in the North West part but includes people from all over the country.

Age-specific prevalence was $55 \%$ in children $0-16$ years, $47 \%$ in those $17-30$ years in our study. One of the studies published in 2002, with 4,462 subjects under the age of 30 in nine provinces of Turkey identified an overall HAV seroprevalence rate of $71.3 \%$ [10]. A study including 450 people aged under 30 conducted in the Eastern part of Turkey showed that seroprevalence was $84 \%$. Frequency of HAV infection in the Eastern part of the country is high, compared to other regions of Turkey [10]. Another study, conducted in Istanbul which included 630 individuals between the ages of 5 and 24 years showed that the seropositivity of HAV in the whole study population was $40 \%$ [12]. A seroprevalence study found that the HAV seropositivity in adolescents was $38 \%$ in 2008 , while the rate in the same region had been $75 \%$ in 1998 [13]. Another study, conducted in the Western part of Turkey, found that the total seropositivity was $44.6 \%$ among the individuals aged under 18 years and emphasised that the seropositivity increases significantly among children at school age and also increases parallel to age [14]. A more recent study conducted in the Western part of Turkey, including 729 children 1-18 years old showed that HAV seropositivity was $29.5 \%$ and that anti-HAV vaccination should be considered for preschool children because teenagers are at risk of infection in this region [15]. Our study shows that half of the children and young adults are seronegative for HAV and our results support that the prevalence of HAV has decreased in recent years.

Anti-HAV seroprevalence in the 31-45 year age group is $73.5 \%$ and for the over 46 years is $89 \%$, in our study. Most of the studies in our country conducted in 2000s revealed that HAV seropositivity was up to $90 \%$ in adulthood. This included young adults older than 26 years old $[8,13,16]$. Some of the studies have shown that the overall HAV prevalence rates declined during the past two decades from almost $90 \%$ to $72 \%$ in Turkey $[6,16]$. Our study has also shown that the seroprevalence rates declined especially in young adults and our results support this changing pattern. The changing pattern of HAV infection (from early childhood to adulthood) has been observed in many developing countries and young adults are at risk of acquiring the infection [17]. Improved sanitation and hygienic conditions have contributed to this changing pattern in our country.

The age seroprevalence studies from the countries in the Middle East region of intermediate endemicity have shown that the immunity rate in this region was 77 to $96 \%$ between the ages of 15-44 years. European countries have a low seroprevalence rate. The immunity rate between the ages of 15-44 years was 28 to 56\% in Western Europe and 47 to $76 \%$ in Eastern Europe [8]. Our results are similar to immunity rates in Europe.

Turkey which is one of the countries of intermediate endemicity, is located on two continents and one part of Istanbul lies in Europe (Western part) and the other part lies in Asia. In countries of intermediate endemicity, WHO recommends childhood vaccination [7] and in our country HAV vaccine has been included in the national immunization program since November, 2012. Since, routine HAV vaccination started only a few years ago and because of the changing pattern of HAV infection in our country, children and young adults should be evaluated carefully; our results show that almost half of them are susceptible to HAV infection People who are seronegative for HAV are at risk of infection and vaccination provides pre-exposure protection from HAV infection $(2,18)$. Costeffective analyses performed in Ireland showed that where HAV immunity is $45 \%$ or less, vaccination is the strategy of choice, and when immunity is greater than $45 \%$, then screening followed by vaccination should be performed [19]. A further study from multiple geographical regions of Turkey can evaluate cost-effectivity in our country.

In conclusion, HAV seropositivity was detected to be strongly age dependent and the seroprevalence of HAV in our region has decreased in recent years. The results of our study indicate that a majority of people older than 46 years old are immune to HAV whereas half of people aging 0 to 30 years are susceptible. People who have never contracted HAV and have not been vaccinated against hepatitis $\mathrm{A}$ are at risk of infection. HAV vaccination provides preexposure protection from HAV infection therefore susceptible people, especially children and young adults, should be considered to be screened and vaccined if necessary.

\section{Informed Conflict of Interest}

No conflict of interest was declared by the authors.

\section{Financial disclosure}

The authors have nothing to declare. 


\section{References}

1. Curry MP, Chopra S. Acute viral hepatitis. In: Mandell GL, Bennett JE, Dolin R, editors. Hepatitis A. Mandell, Douglas, and Bennett's Principles and Practice of Infectious Diseases. 6th ed. Philadelphia: Churchill Livingstone, 2005:1426-40.

2. Lemon SM.Type A viral hepatitis: epidemiology, diagnosis, and prevention. Clin Chem 1997; 43:1494-99.

3. Lee H, Cho HK, Kim JH, Kim KH. Seroepidemiology of hepatitis A in Korea: changes over the past 30 years. J Korean Med Sci 2011;26:791-6. doi: 10.3346/jkms.2011.26.6.791

4. World Health Organization. Hepatitis A vaccines: WHO positionpaper. Wkly Epidemiolog Rec 2000; 75: 38-42. http://www.who.int/wer/pdf/2000/wer7505.pdf

5. Saffar MJ, Abedian O, Ajami A, et al. Age-specific seroprevalence of anti-hepatitis A antibody among 1-30 years old population of Savadkuh, Mazandaran, Iran with literature review. Hepat Mon 2012;12:326-32. doi: 10.5812/ hepatmon. 6035

6. Jacobsen KH, Koopman JS. Declining hepatitis A seroprevalence: a global review and analysis. Epidemiol Infect 2004;132:1005-22. doi: 10.1017/S0950268804002857

7. Kurugol Z, Aslan A, Turkoglu E, Koturoglu G. Changing epidemiology of hepatitis A infection in Izmir, Turkey. Vaccine 2011;29:6259-61. doi: 10.1016/j.vaccine.2011.06.069

8. Jacobsen KH. The global prevalence of hepatitis A virus infection and susceptibility: a systematic review. Geneva, Switzerland: World Health Organization, 2009;10:188-204. WHO/IVB/10.01

9. Ceyhan M, Yildirim I, Kurt N, et al. Differences in hepatitis A seroprevalence among geographical regions in Turkey: a need for regional vaccination recommendations. J Viral Hepat 2008;15:69-72. doi: 10.1111/j.1365-2893.2008.01034.x.

10. Kanra G, Tezcan S, Badur S; Turkish National Study Team. Hepatitis A seroprevalence in a random sample of the Turkish population by simultaneous EPI cluster and comparison with surveys in Turkey. Turk J Pediatr 2002;44:204-10.

11. Vancelik S, Guraksin A, Alp H. Hepatitis A seroepidemiology in Eastern Turkey. East Afr Med J 2006;83:86-90.

12. Ceran N, Yüksel Kocdogan F, Mert D, et al. Hepatitis A seroprevalence in children and young adults in Istanbul, Turkey: seroprevalence change and associated factors. J Viral Hepat 2012;19:72-6. doi: 10.1111/j.13652893.2011.01454.x.

13. Turker K, Balcı E, Batı S, Hasçuhadar M, Savaş E. In our country, changing epidemiology of hepatitis A infection. Turk Mikrobiyol Cem Derg 2011;41:143-8. doi:10.5222/ TMCD.2011.143

14. Tosun S, Ertan P, Kasirga E, Atman U. Changes in seroprevalence of hepatitis A in children and adolescents in Manisa, Turkey. Pediatr Int 2004;46:669-72. doi:10.1111/ j.1442-200x.2004.01969.x

15. Halicioglu O, Akman SA, Tatar B, Atesli R, Kose S. Hepatitis A seroprevalence in children and adolescents aged 1-18 years among a low socioeconomic population in Izmir, Turkey. Travel Med Infect Dis 2012;10:43-7. doi:10.1016/j. tmaid.2012.01.001

16. Mistik R. Hepatit A Virus enfeksiyonunun epidemiyolojisi. Tabak F, Tosun S, editörler. Viral Hepatit 2013. İstanbul: İstanbul Tip Yayınevi, 2013:15-23.

17. Melhem NM, Jaffa M, Zaatari M, Awada H, Salibi NE, Ramia $\mathrm{S}$. The changing pattern of hepatitis A in Lebanese adults. Int J Infect Dis 2015;30:87-9. doi:10.1016/j.ijid.2014.10.007

18. Elizee PK, Alavian SM. Prevention of hepatitis a virus infection, need to vaccinate or not? Int $\mathrm{J}$ Prev Med 2013;4:863-5.

19. Rajan E, Shattock AG, Fielding JF. Cost-effective analysis of hepatitis A prevention in Ireland. Am J Gastroenterol 2000;95:223-6. doi:10.1111/j.1572-0241.2000.01689.x 